MOL2NET, International Conference Series on Multidisciplinary Sciences Insert the title of the workshop here

\title{
sciforum
}

Isolation, Characterization, and Application of Bacteriophages against Salmonella enterica.

Ismahen Akremi ${ }^{a}{ }^{*}$, Wided Brabra ${ }^{\text {a,b }}$, Mouna Jlidi ${ }^{a}$, Adel Haj Brahim ${ }^{a}$, Manel Ben Ali ${ }^{a, b}$, Mamdouh Ben Ali ${ }^{a, b *}$

${ }^{a}$ Laboratory of Microbial Biotechnology, Enzymatics and Biomolecules (LBMEB), Center of Biotechnology of Sfax (CBS), University of Sfax, Road of Sidi Mansour km 6, PO Box 1177 Sfax 3018, Tunisia.

${ }^{b}$ Astrum Biotech, Business incubator, Center of Biotechnology of Sfax (CBS), University of Sfax, Road of Sidi Mansour km 6, PO Box 1177 Sfax 3018, Tunisia.

\begin{tabular}{|l|l|}
\hline Graphical Abstract & $\begin{array}{l}\text { Abstract. } \\
\text { Salmonella infection is an important food borne } \\
\text { consumer health concern that can be mitigated } \\
\text { during food processing. Bacteriophage therapy } \\
\text { imparts many advantages over conventional } \\
\text { chemical preservatives including pathogen } \\
\text { specificity, natural derivation, potency, and } \\
\text { providing a high degree of safety. The objective } \\
\text { of this study aimed to isolate and characterize } \\
\text { phages that effectively control Salmonella food } \\
\text { contamination. A total of } 36 \text { bacteriophages } \\
\text { infecting Salmonella enterica were isolated, } \\
\text { tested at different pH ranging from } 3 \text { to 11, and } \\
\text { high temperatures from 37 }{ }^{\circ} \mathrm{C} \text { to } 70 \circ \mathrm{C}, \text { then } \\
\text { tested against 11 strains in order to define their } \\
\text { host range. The kinetics of phages have been } \\
\text { studied in order to understand their lysis process. } \\
\text { The genomic restriction profile of the isolated } \\
\text { phages was interpreted following the action of 5 } \\
\text { restriction enzymes (BamHI, EcoRI, HindIII, } \\
\text { and EcoRV and NdeI). Tests of the application }\end{array}$ \\
\hline
\end{tabular}




\begin{tabular}{|l|l|}
\hline \hline & $\begin{array}{l}\text { of these phages were carried out on a food } \\
\text { matrix in order to evaluate their ability to fight } \\
\text { against Salmonella enterica. The results } \\
\text { obtained are very encouraging, showing the } \\
\text { possibility of using the bacteriophages isolated } \\
\text { against Salmonella enterica, which can have a } \\
\text { significant socio-economic impact. }\end{array}$ \\
\hline
\end{tabular}

\section{Introduction (optional)}

The Gram-negative bacterial genus Salmonella belongs to the family Enterobacteriaceae, order Enterobacteriales, class Gammaproteobacteria and phylum Proteobacteria. Salmonella is the most common cause of the acquired bacterial foodborne illness named as Salmonellosis. Almost all strains of Salmonella are pathogenic and are predominately harbored in eggs, meats, animal products such as milk, or contaminated vegetables causing disease in human beings consuming the contaminated food. Foodborne illness due to Salmonella-contaminated pork products is an important public health problem, causing economic losses, because the presence of this pathogen can limit meat exports from pork-producing countries (Rostagno and Callaway, 2012).

Bacteriophages (phages) are natural predators of bacteria and are ubiquitous in the environment (Rohwer and Edwards, 2002). The use of bacteriophages is an alternative to antibiotics that has been increasingly used on animal production experiments, and it was suggested for prophylactic control and reduction of pathogens (Mahony et al., 2011). The extension of phage biocontrol to food applications has been investigated for a long time until now (Greer, 2005; Kazi M and Annapure US, 2016).

Keeping in view the great efficacy of bacteriophages in controlling pathogens, the present study aims to isolate and characterize bacteriophages which effectively target human pathogenic Salmonella. Moreover, we seek to establish the potential of candidate phages to control Salmonella contamination in ready to eat foods including milk.

\section{Materials and Methods (optional)}

Sample collection: Samples were taken in the city of Sfax-Tunisia, wastewater collection point / station, Route Matar Ceinture Bourguiba, wastewater Industrial Zone Sidi Salem, Route Gabes and chicken excrement. The samples were taken at the beginning of June 2020. Samples were taken from untreated wastewater $15-20 \mathrm{~cm}$ deep. The samples were distributed into sterile transparent glass vials, leaving an air volume of approximately $1 / 10$ of the vial volume and transported as quickly as possible to the laboratory under isothermal conditions of $4{ }^{\circ} \mathrm{C}$ and manipulated the same day of collection. 
http://sciforum.net/conference/mol2net-05

Bacteriophage isolation, purification, and concentration: Samples were centrifuged at 10,000 g for 10 min to remove solid particles and bacteria were excluded using a $0.22 \mathrm{~mm}$ sterile filter. As for chicken excrement, samples were dissolved in $10 \mathrm{~mL} / \mathrm{g}$ of PBS before centrifugation.

For enrichment, Salmonella enteric strain were used as the host strain was grown $8-10 \mathrm{~h}$ at $37^{\circ} \mathrm{C}$ in tryptic soy broth (TSB) to obtain pure bacterial cultures. Two hundred microliter overnight cultures were inoculated into $10 \mathrm{~mL}$ TSB and incubated at $37^{\circ} \mathrm{C}$ shaker at the speed of $160 \mathrm{rpm}$ for $6-8 \mathrm{~h}$ to reach the exponential growth phase. $10 \mathrm{~mL}$ Salmonella cultures were mixed with $40 \mathrm{~mL}$ TSB media and $10 \mathrm{~mL}$ filtered sample to amplify the collected phages. Amplified phages were isolated by centrifugation at $8000 \mathrm{~g}$ for $15 \mathrm{~min}$ and filtration using $0.22 \mathrm{~mm}$ sterile filter. Both large and small phage plaques were picked. To do so, dilution series of isolated phage samples were assessed on plates covered in a lawn of target bacteria. Individual plaques were picked and re-purified for three consecutive passages.

Characterization of selected phages: $\mathrm{pH}$, thermal stability and morphology of phages were tested using the method of Huang et al., (2018) to determine the stability of phages.

DNA analysis of phages: The nucleic acid of the phage was extracted according to a previously described method (Sambrook and Russel, 2001) using 10\% SDS and proteinase K (10 mg/mL). BamHI, EcoRI, EcoRV, HindIII and NdeI were chosen to use as the enzyme for restriction enzyme digestion.

Application and assays in Milk: Fresh skim milk was prepared using the skim milk powder from BDDifco Company, United States and was sterilized according to manufacturer's instructions. $100 \mathrm{~mL}$ phage lysates $\left(10^{6} \mathrm{CFU} / \mathrm{mL}\right)$ were added to milk inoculated with $10 \mathrm{~mL}$ Salmonella enterica an MOI of $1\left(10^{7} \mathrm{CFU} / \mathrm{mL}\right)$ or MOI of $100\left(10^{5} \mathrm{CFU} / \mathrm{mL}\right)$. Equal volume of SM buffer was added to the milk in the control group. Samples were incubated at 4 or $28^{\circ} \mathrm{C}$. After $0,1,2,4$, and $6 \mathrm{~h}$ of incubation, aliquots were drawn to determine viable bacterial counts $(\mathrm{CFU} / \mathrm{mL})$ and phage concentrations (PFU/mL). Recoverable bacteria were enumerated by serial plating. Phage concentration was assessed by centrifuging the aliquot at $11,000 \mathrm{~g}$ for $10 \mathrm{~min}$ and determining phage present in the supernatant.

\section{Results and Discussion (optional)}

Isolation and evaluation of host range of phages: a total of 36 phages against Salmonella enterica were isolated from various environments in Sfax (wastewater fromRoute Matar Belt Bourguiba, chicken excrement, and wastewater from Industrial Zone Sidi Salem, Route Gabes) and exhibited a variety of bacteriophage morphologies. Firstly, the three collections of bacteriophages are tested for their ability to infect a broad spectrum of hosts. The spot test method, adapted from the double layer method (Adams 1959), was retained for this first part of the screening. It allows on the one hand identifying which strains is sensitive for each phage and on the other hand to estimate their effectiveness against these strains. Only 28 phages were included in the host range analysis because the other 8 phages did 
MOL2NET, 2019, 5, ISSN:2624-5078

http://sciforum.net/conference/mol2net-05

not reach a titer of $10^{9} \mathrm{PFU} / \mathrm{ml}$ required for host range analysis (Fong et al. 2017; 2019), suggesting a non-Salmonella host or a Salmonella host other than S. enterica.

The host range of a phage is affected by a number of factors. The phage must first and foremost be able to adsorb to the cell surface to be able to initiate infection and the absence or masking of a compatible receptor will prevent this initial interaction (Drulis-Kawa, Majkowska-Skrobek, and Maciejewska 2015). If surface adsorption is successful, entry of phage DNA into the bacterial cell can then be blocked by exclusion systems (Lu and Henning 1994). The modification / restriction systems (Tock and Dryden 2005) and CRISPR block infection by degrading phage DNA shortly after entering the cell cytoplasm (Fineran and Charpentier 2012; Shabbir et al., 2016). All these factors naturally govern and limit the number of phage hosts.

In our case, using phages at high titer $\left(10^{9} \mathrm{PFU} / \mathrm{ml}\right)$, we screened these phage isolates against two Salmonella serotypes to determine their host range, such as lysis of a wide range of Salmonella strains is essential for biological control applications (Goodridge et al. 2018). The two strains representing the Typhimurium serovar were lysed by all phages, which is important given the worldwide association of this serotype with salmonellosis (Andino and Hanning 2015; Tarabees et al. 2017). Regarding the Abony serovar, which was isolated in 2016 from alfalfa sprouts "Alfalfa sprouts" (Oh and Park 2017), all phages show lytic activity against this serovar. Of all the phages tested, no phage crossed the genus border like Escherichia coli, Listeria monocytogenes and Erwinia amylovora, showing that these had the potential to be used for effective control of minimally disturbing Salmonella other microflora present in food. The strict host range is in line with previous phages isolated by different researchers, proving that phages are safe and well-targeted candidates for application in different foods (Huang et al. 2018). The similarity between host ranges indicates that these 28 phages can recognize similar hosts (Kalatzis et al. 2016).

The study of the effect of different incubation temperatures / different $\mathrm{pH}$ on the stability of phages: Some bacteriophages can be resistant to physical and chemical factors, such as low and high temperatures, pH, salinity and ions (Jończyk et al. 2011). Thus, they can settle and persist in extreme environments (Luhtanen et al. 2014). However, depending on the phage used, unsuitable conditions can inactivate the virus by damaging its structural (head, tail, and envelope) and genetic (DNA / RNA) elements. The variation of a factor can by itself modify the sensitivity of phages to other factors (Müller et al. 2011). Maintaining their activity is however important to ensure the stability of phage preparations (Fister et al. 2016).

The thermal and $\mathrm{pH}$ stability of the phages was determined based on the phage titers under various conditions. In this study, we have chosen to determine the work on phages showing a phage titer greater than or equal to 1011 . That is to say to eliminate around 10 phages ( 5 phages from the $1 \mathrm{st}$ collection: M3, M9, M12, M15 and M16 and also 5 phages from the 2nd collection: P1, P5, P10, P11, P12). 


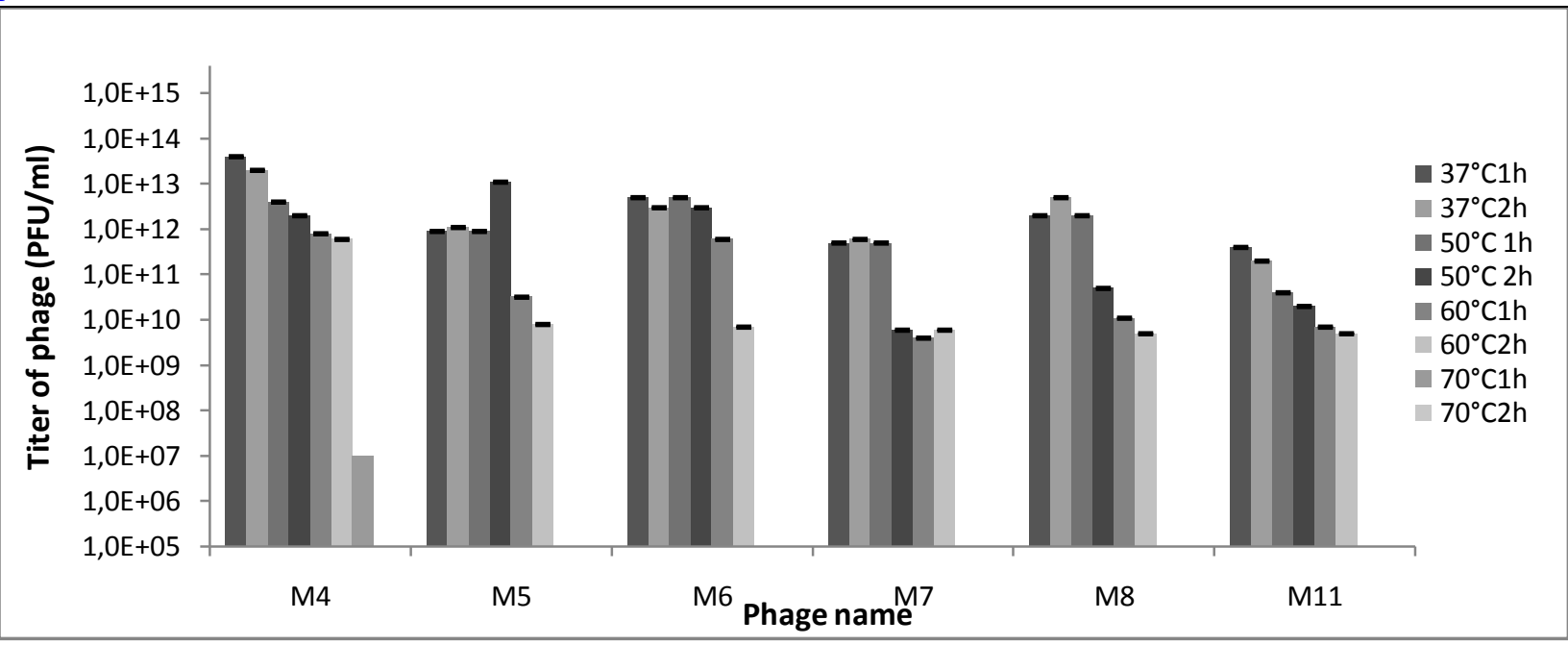

Figure 1: Stability of the phages of the first collection at different temperatures

Beginning with the first collection (wastewater from Route Matar Belt Bourguiba), the stability of phages at $\mathrm{pH}$ was also achieved at $37^{\circ} \mathrm{C}$ for $2 \mathrm{~h}$ and showed the highest stability at $\mathrm{pH} 9$ (Fig 2). The phages showed stability at $\mathrm{pH} 5,7.9$ and 11 while at $\mathrm{pH} 3$ no formation of lysis plaque was observed. The stability of the phages at temperature is tested, for $2 \mathrm{~h}$, from $50{ }^{\circ} \mathrm{C}$ to $70{ }^{\circ} \mathrm{C}$ with a control at 37 ${ }^{\circ} \mathrm{C}$. The phages showed good stability after 1 hour incubation at $50{ }^{\circ} \mathrm{C}$ and $60{ }^{\circ} \mathrm{C}$. Except at $70{ }^{\circ} \mathrm{C}$, only phage M4 is present with a phage titer equal to $10^{7} \mathrm{PFU} / \mathrm{ml}$. After 2 hours of incubation, a slight decrease in the titer of the phages compared to the control (less than $10^{2} \mathrm{PFU} / \mathrm{ml}$ ) is marked at $50{ }^{\circ} \mathrm{C}$ and $60{ }^{\circ} \mathrm{C}$. The non-resistance of phage M4 during the second hour of incubation at $70{ }^{\circ} \mathrm{C}$ (Figure 1).

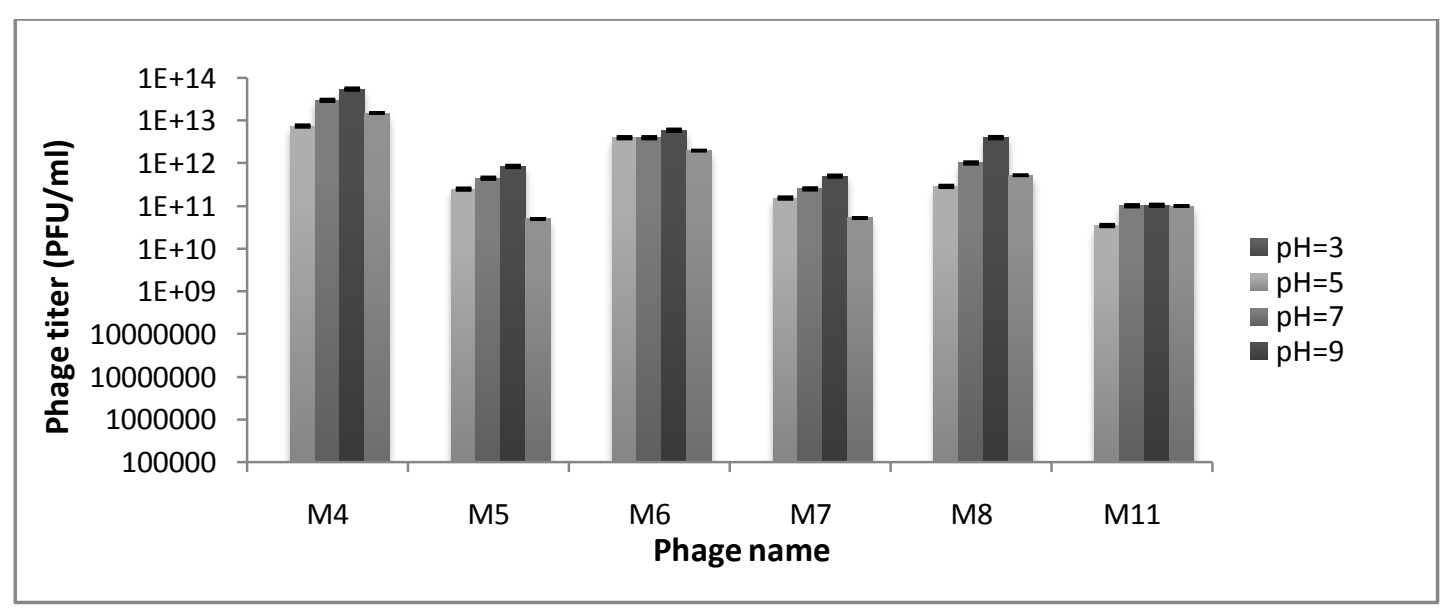

Figure 2: Stability of phages from the first collection at different $\mathrm{pH}$ 


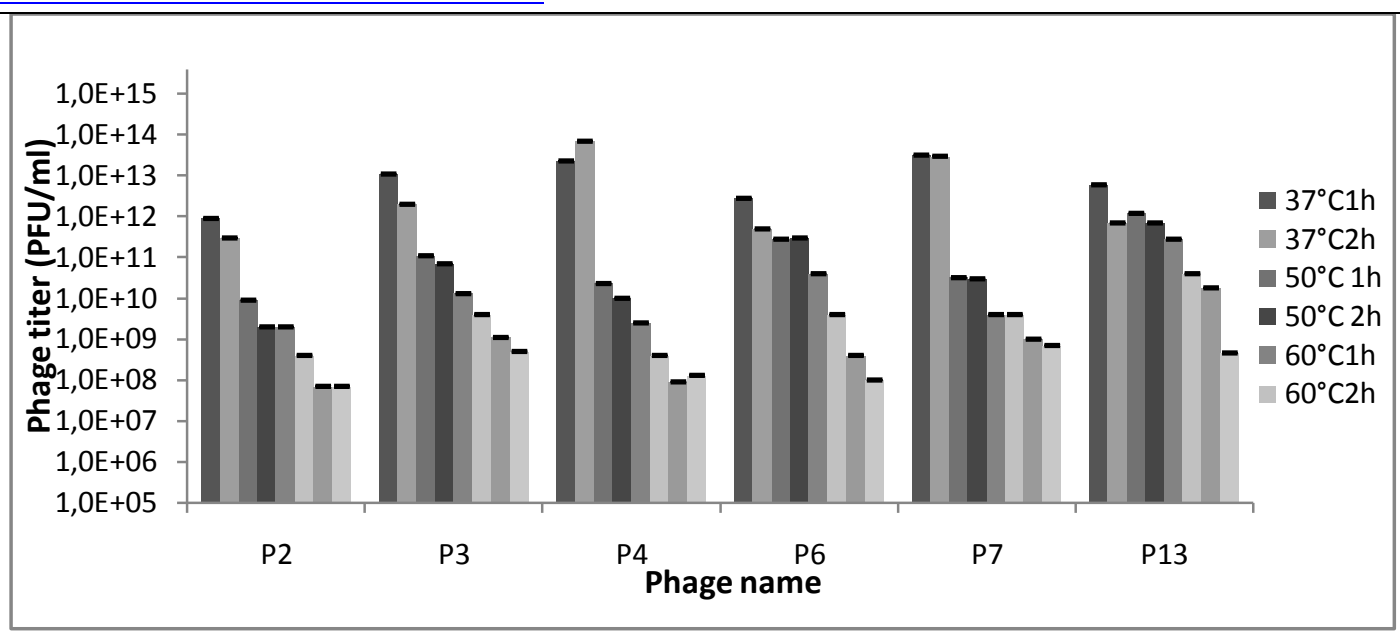

Figure 3: Stability of phages from the second collection at different temperatures

For the collection of phages isolated from chicken excrement, the bacteriophages tested are very stable showing a resistance to $\mathrm{pH}$ ranging from 5 to 11 after $2 \mathrm{~h}$. The recoverable phage titers remained active throughout $\mathrm{pH}$ 5-11 (Figure 4). The titer of the phages decreased at $\mathrm{pH} 3$ (the titer recorded between $10^{8} \mathrm{PFU} / \mathrm{ml}$ and $10^{9} \mathrm{PFU} / \mathrm{ml}$ ). And as regards the temperatures, at $50{ }^{\circ} \mathrm{C}$ and $60{ }^{\circ} \mathrm{C}$, the phages of this collection are stable over time (after 1 and $2 \mathrm{~h}$ ) and showing a slight difference compared to the control. At $70{ }^{\circ} \mathrm{C}$, the phages are stable over time with the phage titer around $10^{8} \mathrm{PFU} / \mathrm{ml}$ (Fig 3).

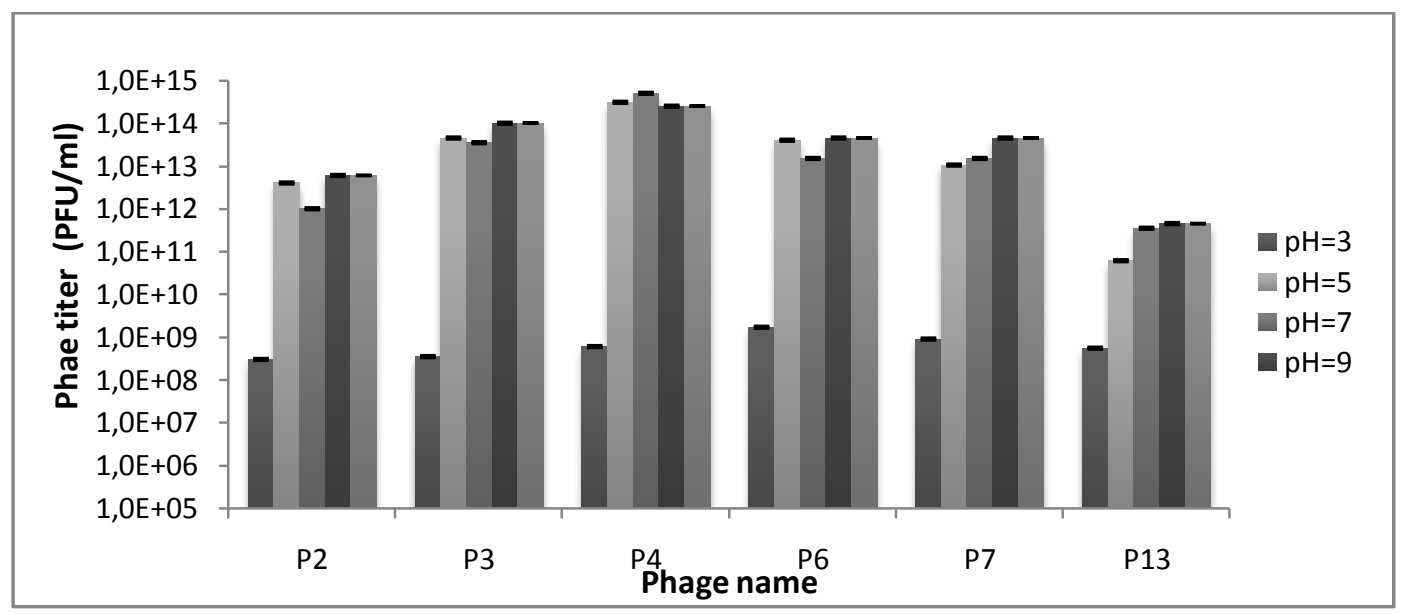

Figure 4: Stability of phages from the second collection at different $\mathrm{pH}$

Finally, the third collection of phages from wastewater from the industrial area of Sidi Salem, after incubation at $\mathrm{pH}$ ranging from 3 to 11 , all phages showing strong stability even at extreme $\mathrm{pH}$ (acidic: pH3; basic: pH11 ) (figure 6).

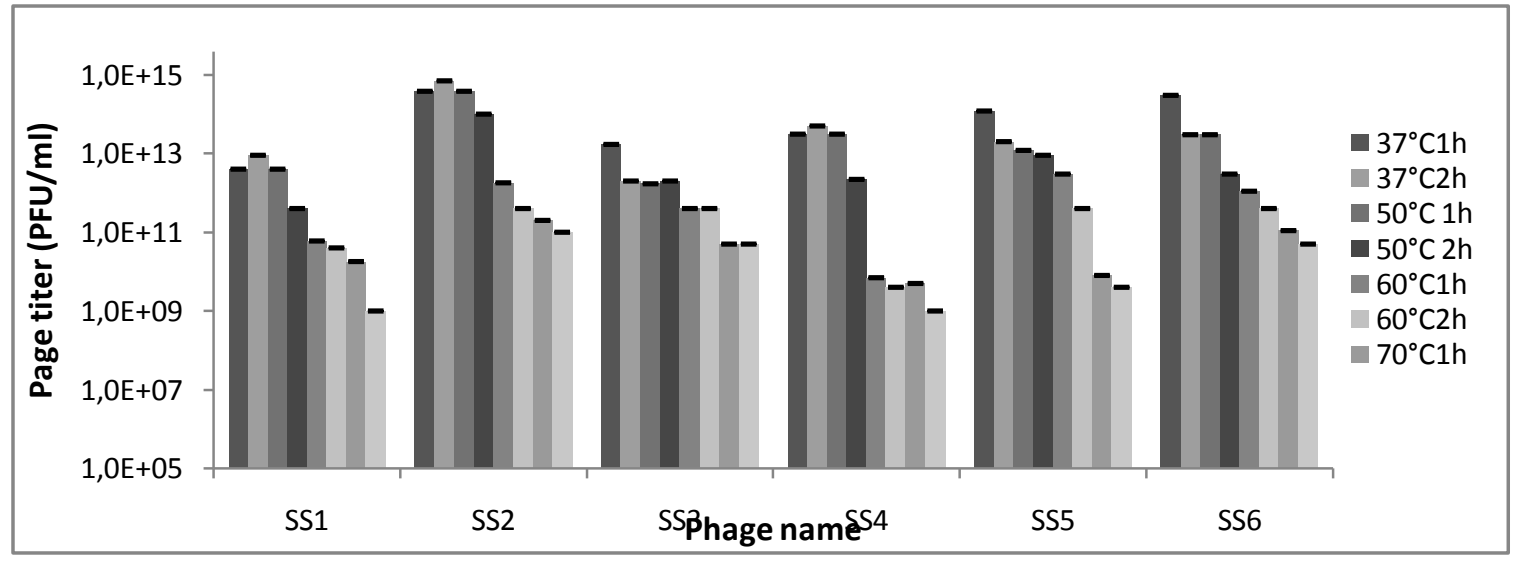


Figure 5: Stability of phages from the third collection at different temperatures

Likewise for the different temperature degrees tested, all phages are stable during the two hours of incubation. The titer of the phages ranging from $10^{9} \mathrm{PFU} / \mathrm{ml}$ to $10^{11} \mathrm{PFU} / \mathrm{ml}$ at $70{ }^{\circ} \mathrm{C}$ after 2 hours (fig 5).

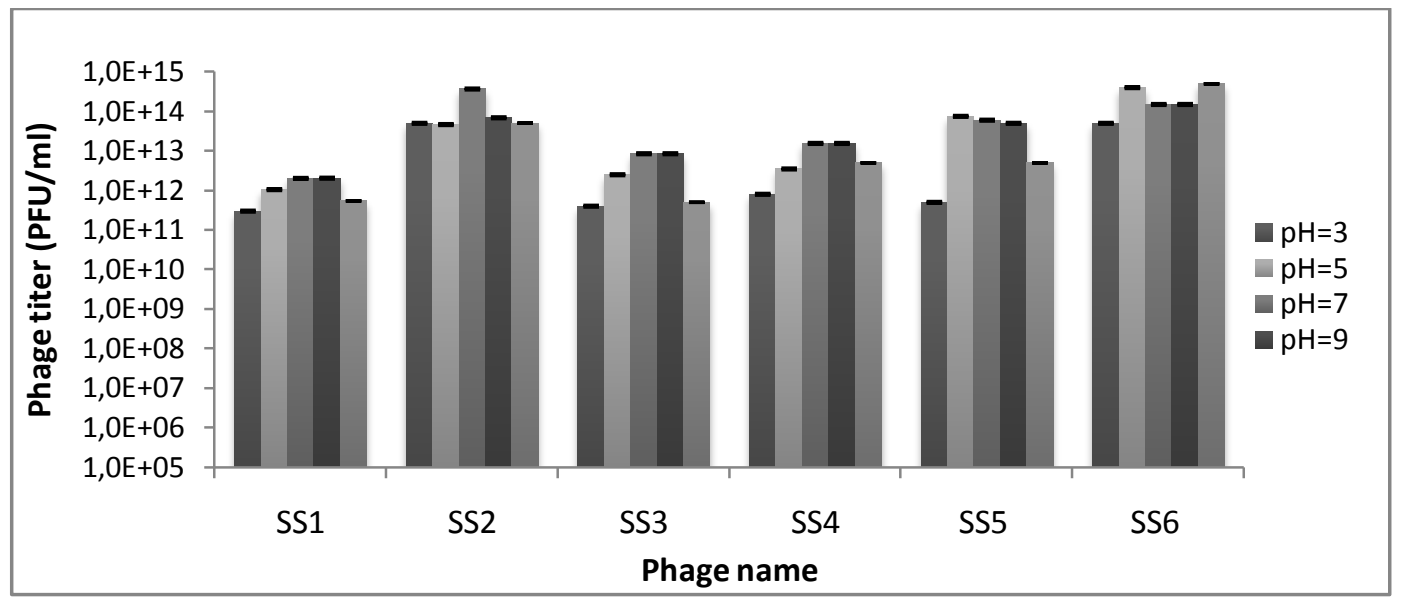

Figure 6: Stability of phages from the third collection at different $\mathrm{pH}$

All phages are active and stable at pH 3 - 5- 7 - 9 and 11 and also at elevated temperatures $37{ }^{\circ} \mathrm{C}, 50$ ${ }^{\circ} \mathrm{C}, 60{ }^{\circ} \mathrm{C}$ and $70{ }^{\circ} \mathrm{C}$, with the exception of phages M4, M5, M6, M7, M8 and M11 are not active at $\mathrm{pH} 3$ and temperature $70{ }^{\circ} \mathrm{C}$ (only phage $\mathrm{M} 4$ resists $70{ }^{\circ} \mathrm{C}$ for 1 hour of incubation with a phage titer equal to $10^{7} \mathrm{PFU} / \mathrm{ml}$ ). The phages of the third collection are found to be the most stable at extreme $\mathrm{pH}$ conditions and high temperatures. As a result, phages can be applied in a wide range of foods due to their high $\mathrm{pH}$ stability $(\mathrm{pH} 3-11)$ and thermal stability $\left(37^{\circ} \mathrm{C}-70^{\circ} \mathrm{C}\right)$.

The tolerance of bacteriophages to $\mathrm{pH}$ and temperature were similar or even better than previously reported phages having a $\mathrm{pH}$ of 4 to 10 and $60{ }^{\circ} \mathrm{C}$, pH of 4 to 11 and $70{ }^{\circ} \mathrm{C}$ (Bao et al. 2015) and pH of 4 at 11 and $60{ }^{\circ} \mathrm{C}$ reported by (Kim et al. 2019) for phages applied against $S$. Enteritidis. Applying phages with a better range can give a wider window of application in food products with lower or higher $\mathrm{pH}$ and with heat treatment. Indeed, phages which resist high temperature have considerable potential to control or eliminate Salmonella spp. during pasteurization, thus allowing more efficient control of bacterial contamination (Kim et al. 2019) as the application of heat and $\mathrm{pH}$ resistant phages adds an advantage to the treatment against pathogens, as only heat or $\mathrm{pH}$ cannot completely kill pathogens. This argument is supported by the data provided (Lambertz et al. 2012) showing the existence of pathogens even after heat treatment of meat products. Some studies show a prevalence of pathogens below $100 \mathrm{CFU/g} \mathrm{(Modzelewska-Kapituła} \mathrm{and} \mathrm{Maj-Sobotka} \mathrm{2014)} \mathrm{but} \mathrm{some} \mathrm{contradict} \mathrm{this}$ and even show more than $100 \mathrm{CFU} / \mathrm{g}$ (Garrido, García-Jalón, and Vitas 2010). In addition, the phages of the first collection were found to be sensitive to acidic conditions ( $\mathrm{pH} 3$ ) and high temperatures (70 ${ }^{\circ} \mathrm{C}$ ), and therefore, its application can be controlled. Phages can be completely inactivated if necessary by adjusting $\mathrm{pH}$ and temperature (Huang et al. 2018). 
Restriction profile of phage DNA; Each more efficient phage in its collection: M4 of the first collection, P3 of the second collection, and SS2 of the third are chosen for the digestion of the DNA of isolated bacteriophages, the action of 5 restriction enzymes was tested ( BamHI, EcoRI, HindIII, EcoRV and NdeI). Digestion of genomic DNA from phages P3, M4 and SS2 by HindIII shows restriction profiles that are not clearly visible and are difficult to interpret. However, those obtained by the use of BamHI, EcoRI, EcoRV and NdeI do not show bands.

Application of a phage cocktail on milk: To simulate food processing conditions before packaging and storage, temperatures $28{ }^{\circ} \mathrm{C}$ and $4{ }^{\circ} \mathrm{C}$ were chosen in the present study to represent ambient temperature and storage temperature, respectively (Huang et al. 2018). In addition, the experiment was designed to replicate the interaction between bacteria and bacteriophages in food within 6 hours, due to the limited time for processing phages in food processing (Parveen et al. 2017).

The phage products of Salmonella have been approved for application to meat and poultry products as well as to fresh and processed fruits and vegetables (Sharma 2013). In addition, previous studies have demonstrated the effectiveness of bacteriophages as biological control agents in fresh produce, such as lettuce (Spricigo et al. 2013), milk (Guenther et al. 2012), (Huang et al., 2018) and meat (Hungaro et al. 2013).

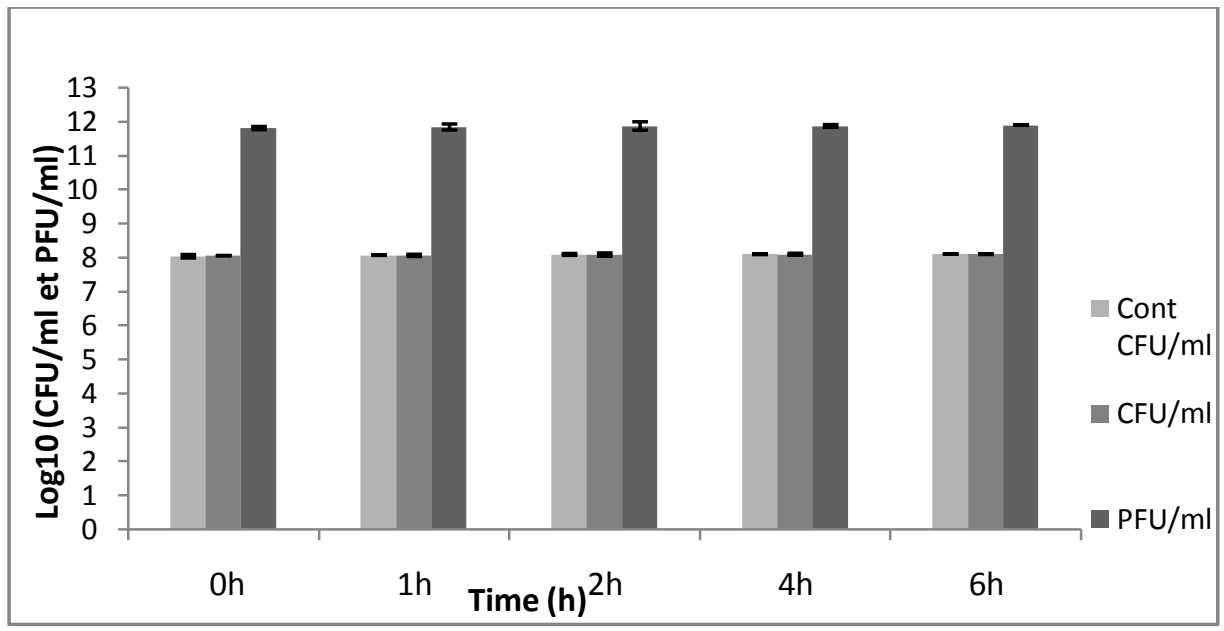

Figure 7: The application of phage cocktail (M4, P3 and SS2) at $4{ }^{\circ} \mathrm{C}$ with $\mathrm{MOI}=1$

When applied to a food matrix (milk) at an MOI of 1 at $4{ }^{\circ} \mathrm{C}$, the cocktail did not confer an appreciable change in the viable statistics of Salmonella CFU or of PFU phage replication. The low temperature is one of the reasons for the low virulence of the phage because the low temperatures hamper the growth of microbes and the phages depend on the multiplication of its host (Figure 7).

However, when applied at an MOI of 1 at $28{ }^{\circ} \mathrm{C}$, the titer of the phage cocktail increased during $6 \mathrm{~h}$ of incubation at $13.8 \log 10 \mathrm{PFU} / \mathrm{mL}$ (Figure 8). The reduction in the number of bacteria was observed consistently following phage infection, it was evident at $28{ }^{\circ} \mathrm{C}$ and an MOI of 1 . Administration of the cocktail reduced recoverable Salmonella by $2.42 \log 10 \mathrm{CFU} / \mathrm{mL}$ compared to the excluded phage control (efficiency reached 25.4\% (control $=9.5 \log 10 \mathrm{CFU} / \mathrm{mL}$; test $=7.08 \log 10 \mathrm{CFU} / \mathrm{mL}$ )). This may be due to the exposure of phages to a high density of bacterial cells, resulting in an increase in 
MOL2NET, 2019, 5, ISSN:2624-5078

http://sciforum.net/conference/mol2net-05

phage titer during replication. The phage cocktail largely suppressed the proliferation of Salmonella resulting in a decrease of $0.72 \log 10 \mathrm{CFU} / \mathrm{mL}$. In the absence of phage treatment, Salmonella was multiplied by $1.51 \log 10 \mathrm{CFU} / \mathrm{mL}$. The reason for the increase in the number of Salmonella during incubation in milk at $28^{\circ} \mathrm{C}$ can be attributed to favorable replication conditions. This argument is consistent with a related study in which the incubation of chocolate milk was artificially spiked with $103 \mathrm{CFU} / \mathrm{mL}$ of Salmonella Typhimurium. No detectable bacterial multiplication was observed for up to 6 days after incubation at $8^{\circ} \mathrm{C}$. However, when incubated at $15{ }^{\circ} \mathrm{C}$, Salmonella Typhimurium multiplied rapidly after $48 \mathrm{~h}$ after inoculation (Guenther et al. 2012). On the other hand, the storage temperature can also influence the stability of the phage or the kinetics of replication. As detailed in another study, several distinct phages were applied in milk against Salmonella at 4 and $25^{\circ} \mathrm{C}$, resulting in varying trends (Bao et al. 2015).

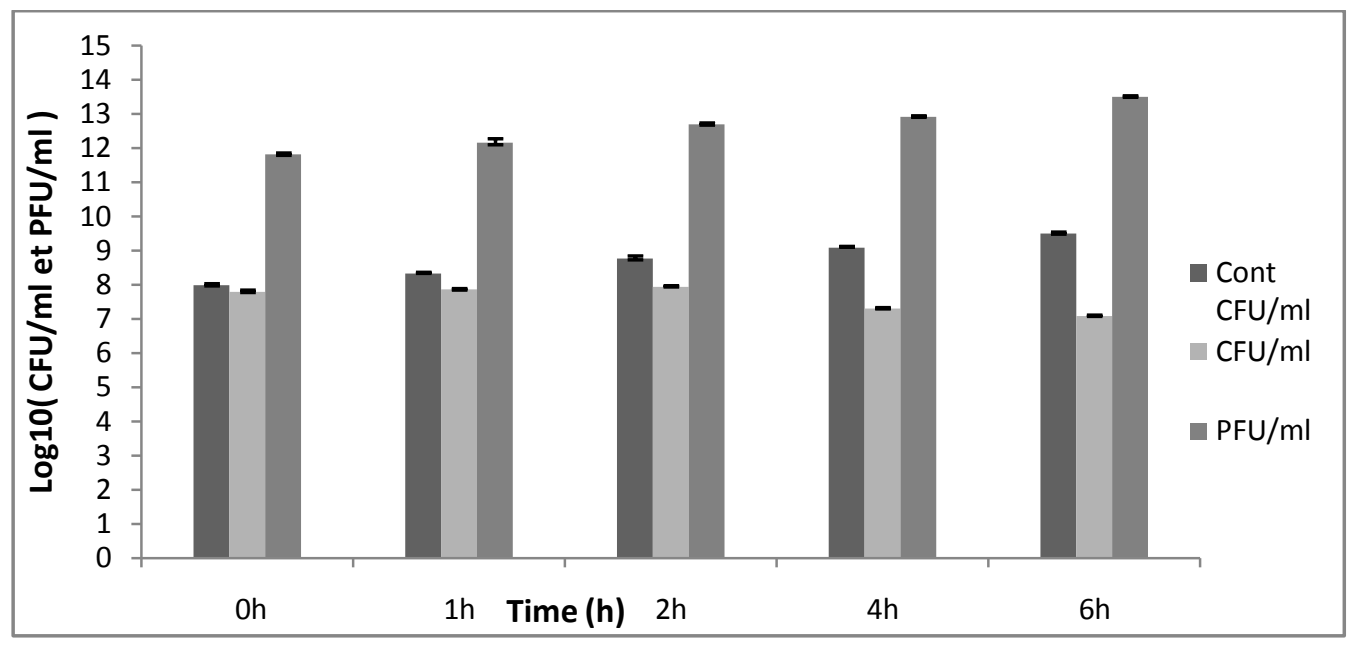

Figure 8: The application of phage cocktail (M4, P3 and SS2) at $28^{\circ} \mathrm{C}$ with MOI $=1$

The effectiveness of the phage cocktail was found to be relatively lower at $4{ }^{\circ} \mathrm{C}$, compared to that at $28{ }^{\circ} \mathrm{C}$. A similar result was also reported in a previous study on the efficacy of phage LPSTA1 applied to milk, lettuce and sausage at $4{ }^{\circ} \mathrm{C}$ and $28^{\circ} \mathrm{C}$ (Huang et al. 2018), and phage P7 in beef at $5{ }^{\circ} \mathrm{C}$ and $24^{\circ} \mathrm{C}$ (Bigwood et al. 2008), indicating a smaller reduction in the number of bacteria at $4-5{ }^{\circ} \mathrm{C}$ compared to that at $28-24{ }^{\circ} \mathrm{C}$. Nevertheless, it was revealed that storage at low temperature $\left(5{ }^{\circ} \mathrm{C}\right)$ could prevent the re-growth of bacteria after phage treatment (Guenther et al. 2012), and that the reduction in the number of bacteria persisted during storage even after 10 days (Soni, Nannapaneni, and Hagens 2010).

\section{Conclusions (optional)}

Salmonellosis is a foodborne infection of global importance. It is a zoonotic bacterial disease of national and international health and economic significance.

The application of phages as a means of bio-control is recognized to be one of the safest approaches today. This study was focused on the biological control of Salmonella in the food industry. The overall objective of this topic was to isolate and characterize phages infecting salmonella and to evaluate their efficacy as a means of controlling $S$. enterica. For the isolation, 3 environmental samples were used to 
isolate a total of 36 bacteriophages. Only phages with a high titer reaching $10^{9} \mathrm{PFU} / \mathrm{ml}$ (Fong et al., 2017; Karen Fong, 2019), were subsequently tested by the spot method (Adams, 1959) against 11 strains in order to define his host specter. A prerequisite for the industrial use of the phages selected in this work is the characterization of their genomes and their biological properties. For this, 18 phages (with a titer reached $10^{11} \mathrm{PFU} / \mathrm{ml}$ ) were tested at different $\mathrm{pHs}$ ranging from 3 to 11 , and high temperatures of $37^{\circ} \mathrm{C}$ to $70^{\circ} \mathrm{C}$, marking encouraging results showing their stability under extreme conditions. The genomes of the three isolated phages show restriction profiles are not clearly visible and are difficult to interpret due to the action of 5 restriction enzymes (BamHI, EcoRI, HindIII, and EcoRV and NdeI).

Finally and in order to assess the ability of bacteriophages M4, P3 and SS2 to fight against S. enterica, an application on a food matrix (semi-skimmed milk of delight) was made at two different temperatures: $4^{\circ} \mathrm{C}$ to simulate the storage temperature and $28^{\circ} \mathrm{C}$ to simulate the ambient temperature. The efficiency of the phage cocktail was found to be relatively lower at $4{ }^{\circ} \mathrm{C}$, compared to that at $28^{\circ} \mathrm{C}$ which showed a removal efficiency of $S$. enterica reaching $25.4 \%$.

\section{References (mandatory)}

1- Rostagno MH, Callaway TR. Pre-harvest risk factors for Salmonella enterica in pork production. Food Res Int 2012;45: 634-640.

2- Mahony J, McAuliffe O, Ross RP, Sinderen DV. Bacteriophages as biocontrol agents of food pathogens. Curr Opin Biotechnol 2011; 22:157-163.

3- Greer GG. Bacteriophage control of foodborne bacteria. J Food Prot 2005; 68: 1102-1111.

4- Kazi M, Annapure US. Bacteriophage biocontrol of foodborne pathogens. J Food Sci Technol 2016; 53(3): 1355-1362.

5- Rohwer, F., and R. Edwards. The Phage Proteomic Tree: a genome based taxonomy for phage. J. Bacteriol 2002; 184:4529-4535.

6- Chenxi Huang, Safiullah M. Virk, Jianchun Shi, Yang Zhou, Stephan P. Willias, Mohamed K. Morsy, Hazem E. Abdelnabby, Jie Liu, Xiaohong Wang and Jinquan Li. Isolation, Characterization, and Application of Bacteriophage LPSE1 Against Salmonella enterica in Ready to Eat (RTE) Foods. Frontiers in Microbiology 2018; 2: 1046.

7- Sambrook, J. Molecular Cloning: A Laboratory Manual, [3 volume set] pdf.

8- Adams, Mark Hancock. 1959. « Bacteriophages. » Bacteriophages.

9- Fong, Stephanie A., Amanda Drilling, Sandra Morales, Marjolein E. Cornet, Bradford A. Woodworth, Wytske J. Fokkens, Alkis J. Psaltis, Sarah Vreugde, et Peter-John Wormald. Activity of bacteriophages in removing biofilms of Pseudomonas aeruginosa isolates from chronic rhinosinusitis patients. Frontiers in cellular and infection microbiology, 2017; 7: 418. 
10- Fong, Tremblay, Delaquis, Goodridge, Levesque, Moineau, Suttle, et Wang. Diversity and Host Specificity Revealed by Biological Characterization and Whole Genome Sequencing of Bacteriophages Infecting Salmonella Enterica. Viruses, 2019; 11 (9): 854.

11- Drulis-Kawa, Zuzanna, Grazyna Majkowska-Skrobek, et Barbara Maciejewska. Bacteriophages and Phage-Derived Proteins - Application Approaches. Current Medicinal Chemistry, 2015; 22 (14): 1757-73.

12- Lu, Meng-Ji, and Ulf Henning. Superinfection exclusion by T-even-type coliphages. Trends in microbiology, 1997; 2 (4): 137-139.

13- Tock, Mark R, and David TF Dryden. The Biology of Restriction and Anti-Restriction. Current Opinion in Microbiology, 2005; 8 (4): 466-72.

14- Fineran, Peter C., and Emmanuelle Charpentier. Memory of Viral Infections by CRISPR-Cas Adaptive Immune Systems: Acquisition of New Information. Virology, 2012; 434 (2): 202-9.

15-Shabbir, Muhammad AB, Haihong Hao, M. Z. Shabbir, and Q. Wu. Bacteria vs. Bacteriophages: Parallel Evolution of Immune Arsenals. Z Front. Microbiol, 2016; 7, 1-8.

16-Goodridge, Lawrence, Karen Fong, Siyun Wang, and Pascal Delaquis. Bacteriophage-Based Weapons for the War against Foodborne Pathogens. Current Opinion in Food Science, 2018; 20: 69-75.

17-Andino, A., and I. Hanning. Salmonella Enterica: Survival, Colonization, and Virulence Differences among Serovars. The Scientific World Journal, 2015: 1-16.

18-Tarabees, Reda, Mohamed S. A. Elsayed, Reyad Shawish, Shereen Basiouni, and Awad A Shehata. Isolation and Characterization of Salmonella Enteritidis and Salmonella Typhimurium from Chicken Meat in Egypt. The Journal of Infection in Developing Countries, 2017:11 (04): 314-19.

19- Oh, Jun-Hyun, and Mi-Kyung Park. Recent Trends in Salmonella Outbreaks and Emerging Technology for Biocontrol of Salmonella Using Phages in Foods: A Review. Journal of Microbiology and Biotechnology, 2017; 27 (12): 2075-88.

20- Kalatzis, Panos G., Roberto Bastías, Constantina Kokkari, et Pantelis Katharios. Isolation and Characterization of Two Lytic Bacteriophages, ФSt2 and $\Phi$ Grn1; Phage Therapy Application for Biological Control of Vibrio Alginolyticus in Aquaculture Live Feeds. PLOS ONE, 2016; 11 (3): e0151101.

21-Jończyk, E., M. Kłak, R. Międzybrodzki, and A. Górski. The Influence of External Factors on Bacteriophages_-Review. Folia Microbiologica, 2011; 56 (3): 191-200.

22- Luhtanen, Anne-Mari, Eeva Eronen-Rasimus, Hermanni Kaartokallio, Janne-Markus Rintala, Riitta Autio, and Elina Roine. Isolation and characterization of phage-host systems from the Baltic Sea ice. Extremophiles, 201418 (1): 121-130. 
23-Müller, Ina, Rudi Lurz, Michael Kube, Claudia Quedenau, Wilhelm Jelkmann, and Klaus

Geider. Molecular and Physiological Properties of Bacteriophages from North America and Germany Affecting the Fire Blight Pathogen Erwinia amylovora. Microbial Biotechnology, 2011; 4 (6): 735-45.

24- Fister, Susanne, Christian Robben, Anna K. Witte, Dagmar Schoder, Martin Wagner, and Peter Rossmanith. Influence of Environmental Factors on Phage-Bacteria Interaction and on the Efficacy and Infectivity of Phage P100. Frontiers in Microbiology, 2016; 7.

25- Bao, Hongduo, Pengyu Zhang, Hui Zhang, Yan Zhou, Lili Zhang, and Ran Wang. Bio-Control of Salmonella Enteritidis in Foods Using Bacteriophages. Viruses, 2015; 7 (8): 4836-53.

26- Kim, Hyeongsoon, Minsik Kim, Jaewoo Bai, Jeong-A Lim, Sunggi Heu, and Sangryeol Ryu. Colanic Acid Is a Novel Phage Receptor of Pectobacterium carotovorum subsp. carotovorum Phage POP72. Frontiers in Microbiology, 2019; 10 (02): 143.

27-Lambertz, S. Thisted, C. Nilsson, A. Brådenmark, S. Sylvén, A. Johansson, Lisa-Marie Jansson, et M. Lindblad. Prevalence and Level of Listeria Monocytogenes in Ready-to-Eat Foods in Sweden 2010. International Journal of Food Microbiology, 2012; 160 (1): 24-31.

28- Modzelewska-Kapituła, Monika, et Katarzyna Maj-Sobotka. The Microbial Safety of Ready-toEat Raw and Cooked Sausages in Poland: Listeria Monocytogenes and Salmonella Spp. Occurrence. Food Control, 2014; 36 (1): 212-16.

29-Garrido, Victoria, Isabel García-Jalón, and Ana Isabel Vitas. Temperature Distribution in Spanish Domestic Refrigerators and Its Effect on Listeria Monocytogenes Growth in Sliced Ready-to-Eat Ham. Food Control, 2010; 21 (6): 896-901.

30- Parveen, Salina, Jurgen Schwarz, Fawzy Hashem, and Bob Vimini. Reduction of Salmonella in ground chicken using a bacteriophage. Poultry science, 2017; 96 (8): 2845-2852.

31-Sharma, Manan. Lytic bacteriophages: potential interventions against enteric bacterial pathogens on produce. Bacteriophage, 2013; 3 (2): e25518.

32- Spricigo, Denis Augusto, Carlota Bardina, Pilar Cortés, and Montserrat Llagostera. Use of a bacteriophage cocktail to control Salmonella in food and the food industry. International journal of food microbiology, 2013165 (2): 169-174.

33-Guenther, Susanne, Oliver Herzig, Lars Fieseler, Jochen Klumpp, and Martin J. Loessner. Biocontrol of Salmonella Typhimurium in RTE Foods with the Virulent Bacteriophage FO1-E2. International Journal of Food Microbiology, 2012; 154 (1-2): 66-72.

34- Hungaro, Humberto Moreira, Regina Célia Santos Mendonça, Delaine Meireles Gouvêa, Maria Cristina Dantas Vanetti, et Cláudia Lúcia de Oliveira Pinto. Use of Bacteriophages to Reduce Salmonella in Chicken Skin in Comparison with Chemical Agents. Food Research International, 2013; 52 (1): 75-81. 
35-Guenther, Susanne, Oliver Herzig, Lars Fieseler, Jochen Klumpp, and Martin J. Loessner. Biocontrol of Salmonella Typhimurium in RTE Foods with the Virulent Bacteriophage FO1-E2. International Journal of Food Microbiology, 2012; 154 (1-2): 66-72.

36-Bigwood, T., J.A. Hudson, C. Billington, G.V. Carey-Smith, and J.A. Heinemann. Phage Inactivation of Foodborne Pathogens on Cooked and Raw Meat. Food Microbiology, 2008; 25 (2): 400-406.

37-Guenther, Susanne, Oliver Herzig, Lars Fieseler, Jochen Klumpp, and Martin J. Loessner. Biocontrol of Salmonella Typhimurium in RTE Foods with the Virulent Bacteriophage FO1-E2. International Journal of Food Microbiology, 2012; 154 (1-2): 66-72.

38-Soni, Kamlesh A., Ramakrishna Nannapaneni, and Steven Hagens. Reduction of Listeria monocytogenes on the surface of fresh channel catfish fillets by bacteriophage Listex P100. Foodborne pathogens and disease, 2010; 7 (4): 427-434. 